\title{
The Distribution of Cigarette Smoke Components between Mainstream and Sidestream Smoke
}

\author{
II. Bases *
}

by H. Sakuma, M. Kusama, K. Yamaguchi, T. Matsuki and S. Sugawara

Central Research Institute, The Japan Tobacco and Salt Public Corporation, Yokohama, Japan

\section{SUMMARY}

Yields in sidestream smoke (SS) and mainstream smoke (MS) and sidestream smoke to mainstream smoke distribution ratios (SS/MS) of 34 bases were examined from four types of cigarettes made from Bright, Burley, Turkish and domestic (c.v. Matsukawa) tobacco. Irrespective of tobacco variety, major bases in sidestream smoke were ammonia, nicotine, 3-vinylpyridine, pyridine and 3-hydroxypyridine, and those in mainstream smoke were nicotine, 3-hydroxypyridine, ammonia, 3-picoline and pyridine. SS/ MS ratios of the bases were generally larger than 1.0 and the largest SS/MS ratio was that of ammonia, followed by those of 3-vinylpyridine, 3-cyanopyridine, nicotyrine and pyridine in that order.

The preponderance of bases in sidestream smoke over mainstream smoke might be one of the major causes for the differences in aroma and irritation between sidestream smoke and mainstream smoke.

\section{ZUSAMMENFASSUNG}

Bei Zigaretten aus vier verschiedenen Tabaksorten (Vir* ginia-Tabak, Burley-Tabak, türkischer Tabak und die einheimische japanische Tabakvarietăt Matsukawa) wurde die Menge von 34 Basen im Nebenstromrauch (SS) und im Hauptstromrauch (MS) bestimmt und für diese Verbindungen das Nebenstromrauch/Hauptstromrauch-Verhältnis (SS/MS) ermittelt. Quantitativ am stärksten vertreten waren - unabhängig von der Tabaksorte - im Nebenstromrauch Ammoniak, Nicotin, 3-Vinylpyridin, Pyridin und 3-Hydroxypyridin und im Hauptstromrauch Nicotin, 3-Hydroxypyridin, Ammoniak, 3-Picolin und Pyridin. Das Nebenstromrauch/

“ Received: 14th July 1983 — accepted: 16th December 1983.
Hauptstromrauch-Verhältnis der Basen lag im allgemeinen über 1,0, wobei für Ammoniak der höchste Wert gefunden wurde und 3-Vinylpyridin, 3-Cyanpyridin, Nicotyrin und Pyridin mit jeweils abnehmenden Werten folgten.

Der hinsichtlich Aroma und Reizwirkung zwischen Haupt- und Nebenstromrauch zu beobachtende Unterschied könnte unter anderem vor allem auch darin begründet sein, daß im Nebenstromrauch Basen in stärkerem Ausmaß vorkommen als im Hauptstromrauch.

\section{RÉSUMÉ}

Prenant des échantillons de cigarettes confectionnées a partir de 4 types de tabac différents (Virginie, Burley, tabac turc et variété locale de tabac japonais Matsukawa), on détermina 34 bases dans le courant principal (MS) et le courant secondaire (SS) de la fumée et loon calcula le rapport flux secondaire / flux principal (SS/ MS). Indépendamment du type de tabac étudié, les bases présentes en plus grandes quantités dans le courant secondaire de la fumée étaient: l'ammoniaque, la nicotine, la 3-vinylpyridine, la pyridine et la 3-hydroxypyridine, alors que, dans le courant principal, on trouvait surtout de la nicotine, de la 3-hydroxypyridine, de l'ammoniaque, de la 3-picoline et de la pyridine. Le rapport flux secondaire/flux principal, concernant les bases, se situait généralement au-dessus de 1,0; le taux le plus élevé fut atteint par l'ammoniaque suivie dans l'ordre par la 3-vinylpyridine, la 3-cyanopyridine, la nicotyrine et la pyridine.

Les différences observées entre la fumée du flux principal et la fumée du flux secondaire, eu égard à l'arôme et à l'effect irritant, pourraient s'expliquer entre autres, par une plus grande quantité de bases contenue dans le flux secondaire glutôt que dans le flux principal. 


\section{INTRODUCTION}

The aroma and irritation of sidestream smoke (SS) of tobacco differ from those of mainstream smoke (MS). In order to clarify chemically which components contribute most to these differences, the authors have been studying the distribution of cigarette smoke components between sidestream smoke and mainstream smoke (1).

Many basic compounds, for example ammonia, methylamines, pyridines and pyrazines, have offensive smells and are pungent. It is considered that these basic compounds have a great effect on the aroma and irritation of tobacco smoke (2).

Several studies on the distribution of some basic components between sidestream smoke and mainstream smoke have been published. For example, the distribution of nicotine between sidestream smoke and mainstream smoke was reported by Neurath et al. (3), Jobnson et al. (4) and Yosbida (5), that of ammonia by Brunnemann et al. (6) and Jobnson et al. (4), and that of volatile pyridines by Johnson et al. (4), Brunnemann et al. (7) and Glock et al. (8). However, as can be seen from the recent review of the distribution of various tobacco components between mainstream and sidestream smoke written by Klus and Kubn (9), no definitive studies examining the entire spectrum of bases from ammonia to nicotine have been made.

In this study, the distribution of many bases including ammonia, alkylamines, pyridines and tobacco alkaloids between sidestream smoke and mainstream smoke was examined.

\section{EXPERIMENTAL}

\section{Cigarette Sample and Smoking}

(see Table 1)

The cigarettes used in this study were $70 \mathrm{~mm}$ unblended products, i. e. Bright, Burley, Turkish and domestic (c.v. Matsukawa), similar to those used in the previous study (1). Smoking was also accomplished with the apparatus and conditions described previously (1).

Table 1. Sample cigarettes.
Figure 1.

Analytical scheme for low bolling bases in sidestream smoke.

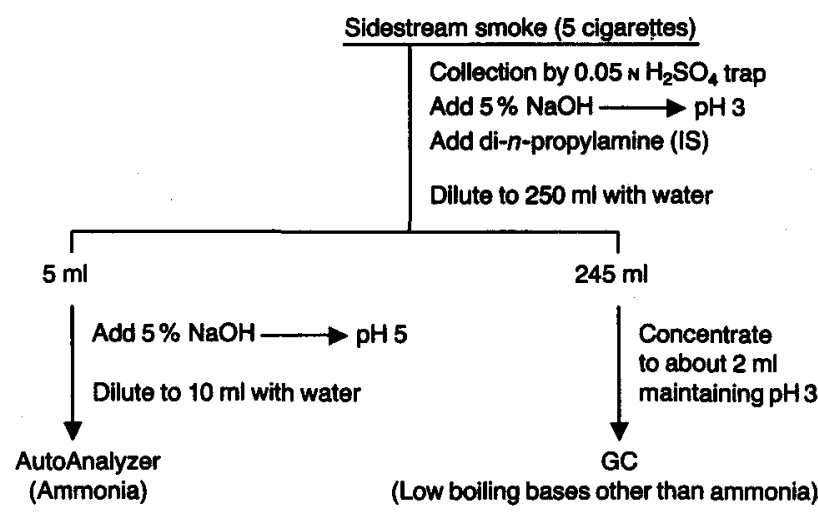

Preparation of Sample for

Gas Chromatographic Analysis

Low Boiling Bases: Sidestream smoke of 5 cigarettes and mainstream smoke of 10 cigarettes were separately led through a series of 2 gas wash bottles containing aqueous $0.05 \mathrm{~N}$ sulfuric acid $(75 \mathrm{ml}$ each for sidestream smoke and $15 \mathrm{ml}$ and $10 \mathrm{ml}$ for mainstream smoke). In the case of sidestream smoke, the $\mathrm{pH}$ of the combined sulfuric acid solution was adjusted to 3 by adding aqueous $5 \%$ sodium hydroxide solution. Also $1 \mathrm{ml}$ of aqueous di-n-propylamine hydrochloride solution $(150 \mu \mathrm{g}$ of di- $n$-propylamine $/ \mathrm{ml}$ ) was added as an internal standard (IS). Then the solution was transferred into a $250 \mathrm{ml}$ volumetric flask and the flask was filled with distilled water.

Five $\mathrm{ml}$ of the solution were removed from the flask for the analysis of ammonia. The $\mathrm{pH}$ was adjusted to 5 with an aqueous sodium hydroxide solution and the solution was diluted to $10 \mathrm{ml}$.

The $\mathrm{pH}$ was maintained at around 3 as the rest of the solution was concentrated to about $2 \mathrm{ml}$ for gas chromatographic analysis of low boiling bases other than ammonia (Fig. 1).

In the case of mainstream smoke, the combined sulfuric acid solution was adjusted to $\mathrm{pH} 5$ and $1 \mathrm{ml}$ of the aqueous di- $n$-propylamine hydrochloride solution was added. Then the solution was diluted to $50 \mathrm{ml}$. A part

\begin{tabular}{lc|c|c|c|c}
\cline { 2 - 6 } & $\begin{array}{c}\text { Weight } \\
(\mathbf{g})\end{array}$ & $\begin{array}{c}\text { Draw } \\
\text { resistance } \\
(\mathrm{mm} \text { w.g. })\end{array}$ & $\begin{array}{c}\text { Air permeability } \\
\left(\mathrm{ml} /\left(\mathrm{min} \cdot \mathrm{cm}^{2} .\right.\right. \\
10 \mathrm{~cm} \text { w.g.) }\end{array}$ & $\begin{array}{c}\text { Mainstream total } \\
\text { particulate matter } \\
(\mathrm{mg} / \text { cigarette })\end{array}$ & $\begin{array}{c}\text { Puff } \\
\text { number }\end{array}$ \\
\hline Bright & $1.059 \pm 0.05$ & $48 \pm 5$ & 10 & 34.6 & 8.3 \\
Burley & $0.966 \pm 0.05$ & $91 \pm 5$ & 10 & 29.0 & 6.3 \\
Turkish & $0.932 \pm 0.05$ & $53 \pm 5$ & 10 & 32.5 & 8.0 \\
Domestic & $0.667 \pm 0.05$ & $48 \pm 5$ & 10 & 30.1 & 7.0 \\
\hline
\end{tabular}


Figure 2.

Analytical scheme for low bolling bases in mainstream smoke.

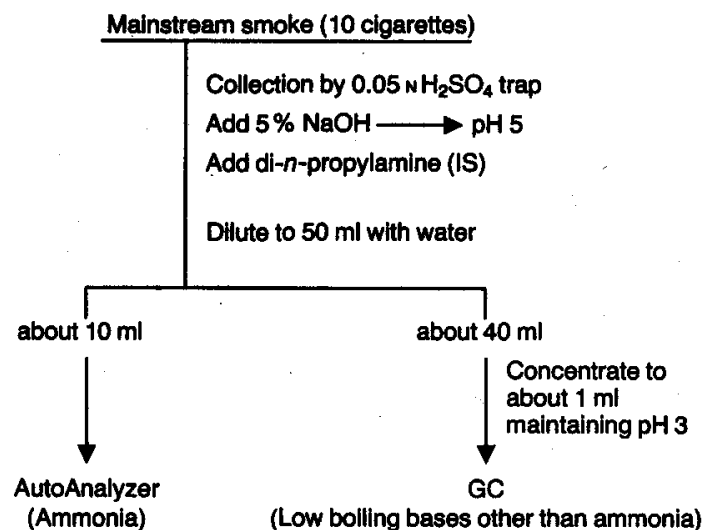

of the solution (about $10 \mathrm{ml}$ ) was used for the analysis of ammonia and the rest of the solution was concentrated to about $1 \mathrm{ml}$ under constant $\mathrm{pH}$ conditions of around 3 (Fig. 2).

Middle and High Boiling Bases: Sidestream smoke and mainstream smoke of 2 cigarettes were separately directed, first onto Cambridge filter pads and subsequently through ice-cooled gas wash bottles containing methanol-hydrochloric acid solution (MS: $40 \mathrm{ml}$ of methanol plus $200 \mu \mathrm{l}$ of concd. hydrochloric acid; SS: $80 \mathrm{ml}$ of methanol plus $200 \mu \mathrm{l}$ of concd. hydrochloric acid).

One ml each of an aqueous 4-tert-butylpyridine solution $(10 \mu \mathrm{l} / 100 \mathrm{ml})$ and an aqueous quinoline solution $(500 \mu \mathrm{l} / 50 \mathrm{ml})$ were added to the methanol-hydro-

Figure 3.

Analytical scheme for middle and high bolling bases in sidestream or malnstream smoke.

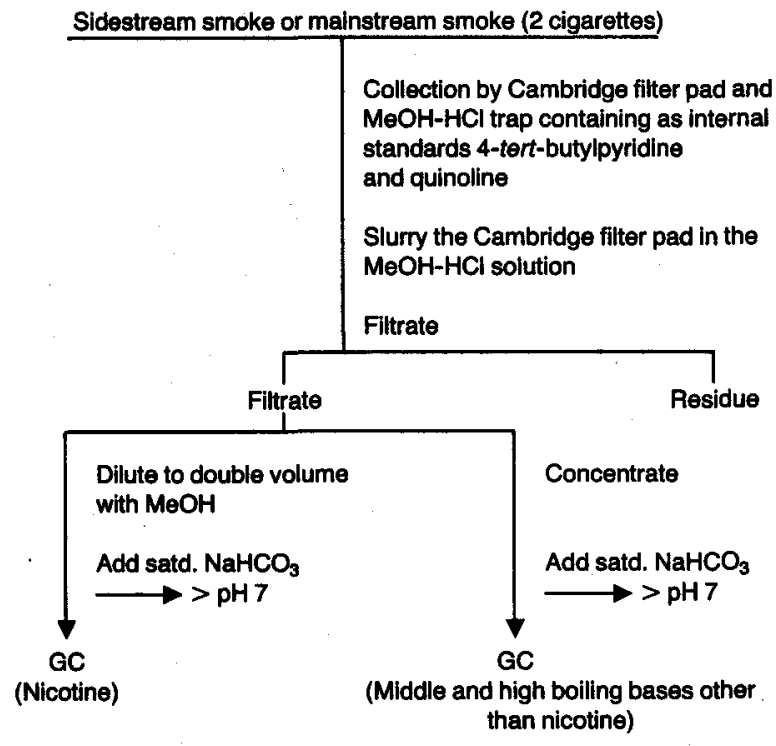

chloric acid solution as internal standards for the analysis of middle and high boiling bases.

Both the sidestream smoke and mainstream smoke obtained as described above were treated in the following manner: the Cambridge filter pad with smoke condensate was slurried in the gas wash bottle and the slurry was filtered. After an aliquot of the filtrate (about $0.2 \mathrm{ml}$ ) was separated for nicotine analysis, the rest of the filtrate was concentrated (MS: about $2 \mathrm{ml}$, SS: about $5 \mathrm{ml}$ ) and the $\mathrm{pH}$ of the concentrate was adjusted to above 7.0 by cooling with ice and adding saturated sodium hydrogen carbonate solution just before the gas chromatographic analysis.

The filtrate separated for nicotine analysis was diluted to double volume with methanol and then the $\mathrm{pH}$ of the solution was adjusted to above 7.0 before the gas chromatographic analysis as described above (Fig. 3).

\section{Gas Chromatography}

Low Boiling Bases otber than Ammonia: A Shimadzu $7 \mathrm{AG}$ gas chromatograph equipped with a flame thermionic detector (Shimadzu FTD-7) was used. The sample solution $(0.3 \mu \mathrm{l})$ was drawn into a microsyringe followed by a small volume of air and about $0.3 \mu \mathrm{l}$ of aqueous $40 \%$ sodium hydroxide solution. Then this was injected onto a glass insert packed with soda lime which served as a dehydrating column (Fig. 4).

A $3 \mathrm{~m} \times 3 \mathrm{~mm}$ inside diameter glass column packed with 60/80 mesh Chromosorb 103 was used and the column oven temperature was maintained at $120^{\circ} \mathrm{C}$ for $4 \mathrm{~min}$ and then programmed to rise to $260^{\circ} \mathrm{C}$ at $4^{\circ} \% \mathrm{~min}$.

Middle and High Boiling Bases: Middle and high boiling bases other than nicotine were analyzed with a Shimadzu 7AG gas chromatograph equipped with a flame thermionic detector (Shimadzu FTD-7). A $25 \mathrm{~m} \times 0.2 \mathrm{~mm}$ inside diameter fused silica capillary column coated with Carbowax 20M was used. The column oven temperature was programmed to rise from $60^{\circ} \mathrm{C}$ to $200^{\circ} \mathrm{C}$ at a rate of $2 \%$ min. Helium was used as a carrier gas at a flow rate of $1.0 \mathrm{ml} / \mathrm{min}$ through the column.

Gas chromatographic conditions for nicotine analysis were the same as for the middle and high boiling bases other than nicotine except that the column oven temperature was kept at $130^{\circ} \mathrm{C}$.

Calibration Curves for Low Boiling Bases other than Ammonia and Middle and High Boiling Bases: Firstly, the sample to internal standard peak area ratios were calculated. The internal standard depended on the boiling range of the base under study, i.e. for low boiling bases, di- $n$-propylamine and for middle and high boiling bases excluding nicotine, 4-tert-butylpyridine was used, while, for nicotine, quinoline was used. Secondly, the calibration curves were obtained by plotting these ratios against the amounts of the authentic compounds in each analysis. 


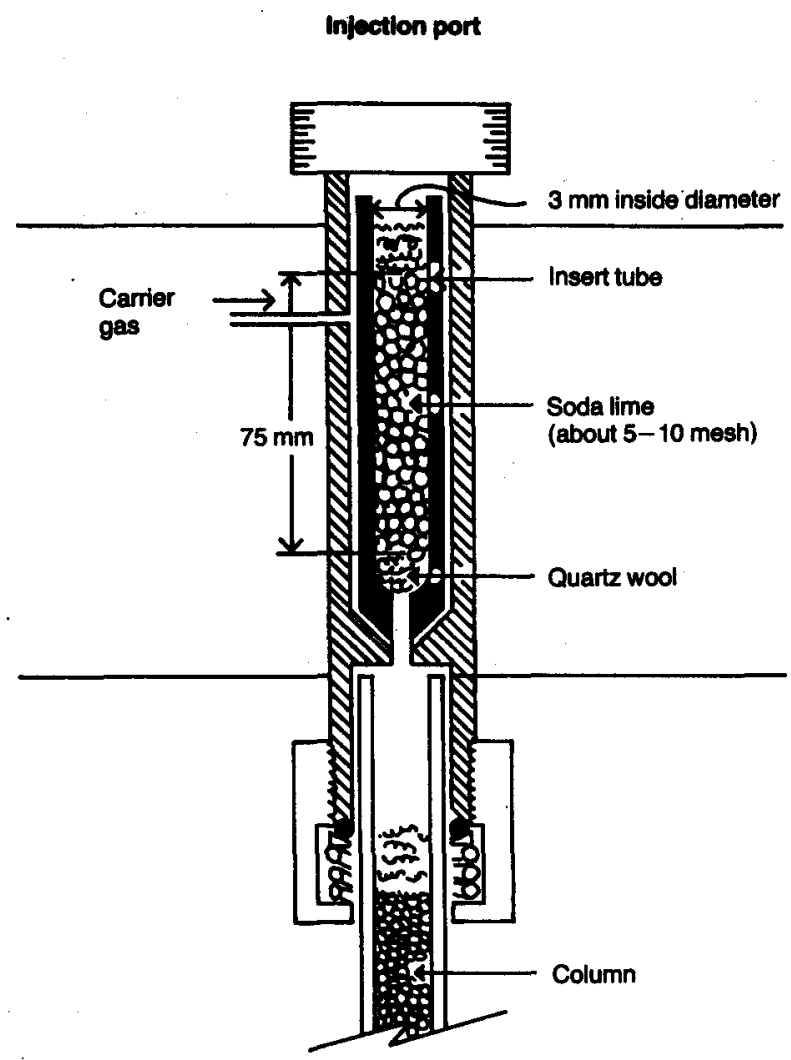

\section{Analysis of Ammonia}

Ammonia in sidestream and mainstream smoke was analyzed photometrically with a Technicon AutoAnalyzer using the analytical method for ammonia in tobacco according to Collins et al. (10) as follows:

1. Buffer (pH: 9): $31.0 \mathrm{~g}$ of boric acid and $8.5 \mathrm{~g}$ of sodium hydroxide were dissolved in water and diluted to 1 liter.

2. Hydrochloric acid: $1.67 \mathrm{ml}$ of concentrated hydrochloric acid was diluted to 2 liters with water.

3. Sodium hypochlorite solution: Commercially available good household bleach having above $5 \%$ available chlorine was used.

4. Alkaline phenol solution: $200 \mathrm{~g}$ of sodium hydroxide and $243 \mathrm{~g}$ of phenol were dissolved in water (diluted to 1 liter) and $0.5 \mathrm{ml}$ of Brij $35^{*}$ was added to the solution.

5. Standard ammonia solution: Ammonia solutions of $100 \mathrm{mg} / 1,50 \mathrm{mg} / 1,25 \mathrm{mg} / 1$ and $2.5 \mathrm{mg} / 1$ were prepared by dissolving $389.2 \mathrm{mg}$ of dried ammonium sulfate in 1 liter of water followed by appropriate dilution.

\footnotetext{
* a surfactant: polyoryethylene dodecyl ether (Kanto Chemical Co., Inc., Tokyo)
}

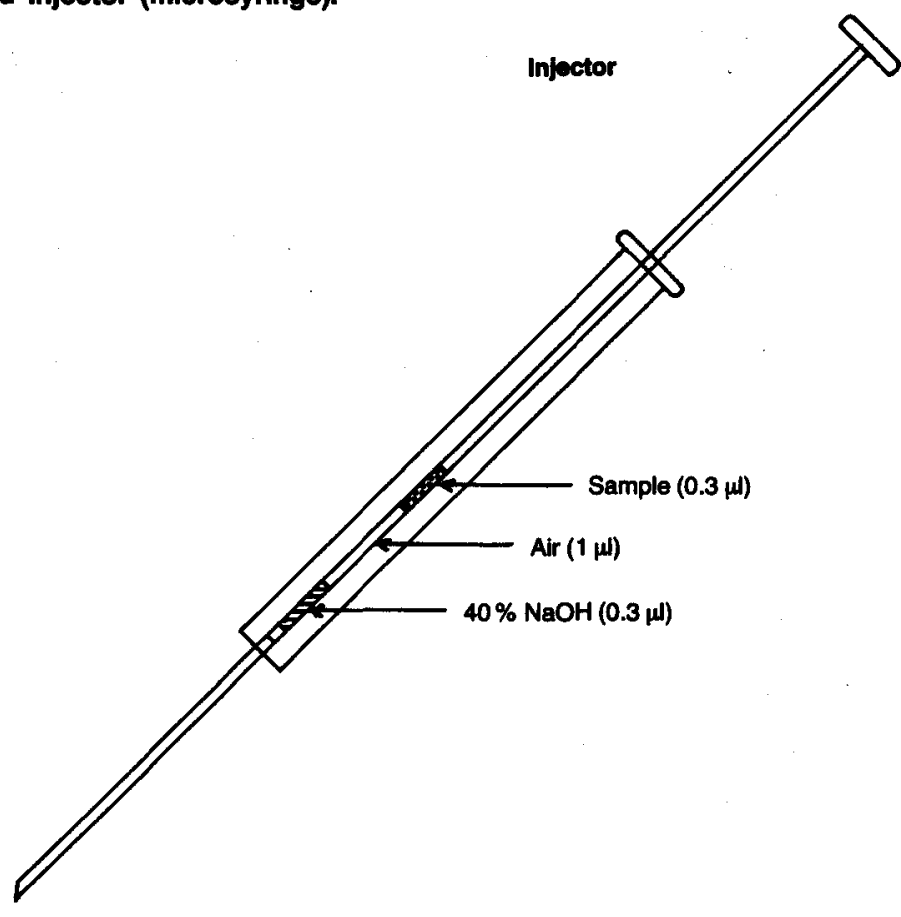

Procedure: The AutoAnalyzer was operated in the normal manner at a sampling rate of $30 / \mathrm{h}$ with a $2: 1$ sample to wash ratio. Sufficient time (longer than $30 \mathrm{~min}$ ) was allowed for the system to become stable with the reagents being pumped and the nitrogen flow adjusted to $200 \mathrm{ml} / \mathrm{min}$ before sampling was begun. Triplicate cups of each sample solution with standards before and after the samples were run. The ammonia content in each sample solution was calculated by using the calibration curve obtained by plotting average peak height against the concentration of ammonia.

\section{RESULTS AND DISCUSSION}

\section{Collection Efficiencies of \\ Low Boiling and Middle and High Boiling Bases}

Collection efficiencies of low boiling bases and middle and high boiling bases in sidestream smoke were examined by analyzing ammonia and nicotine respectively. The amount of ammonia which passed through the trapping system was checked by a third $0.05 \mathrm{~N}$ sulfuric acid trap $(75 \mathrm{ml})$ placed in series with the first two. The amount of nicotine was checked by a second methanol - hydrochloric acid trap $(80 \mathrm{ml}$ of methanol plus $200 \mu \mathrm{l}$ 
of hydrochloric acid) placed in series with the first. The ammonia collected in the third sulfuric acid trap accounted for only $0.05 \%$ of the total quantity collected in all 3 traps. The gas chromatographic analysis of nicotine collected in the second methanol-hydrochloric acid trap gave a trace peak which was too small to count.

\section{Gas Cbromatograms of Low Boiling Bases other than Ammonia}

Figure 5 illustrates typical gas chromatograms of low boiling bases other than ammonia in sidestream smoke and mainstream smoke generated on a $3 \mathrm{~m}$ packed glass column of Chromosorb 103. The peaks corresponding to methylamine, dimethylamine, trimethylamine + ethylamine, isopropylamine, $n$-propylamine, diethylamine, isobutylamine, $n$-butylamine, $N$-methylpyrrolidine, pyrrolidine, isoamylamine, $n$-amylamine and pyridine were identified by retention times by the use of internal standards. Figure 5 shows fairly good separation of these low boiling bases with the exception of only three: trimethylamine, ethylamine and $n$-amylamine. Since hardly any compounds other than the low boiling bases mentioned above seem to be detected by FTD in the chromatograms, identification of the low boiling bases was performed by retention times alone.

The modified injector and co-injection of the sample with sodium hydroxide solution shown in Figure 4 improved the reproducibility of the analytical method for low boiling bases.

\section{Gas Chromatograms of Middle and High Boiling Bases}

Gas chromatograms of the sidestream smoke and mainstream smoke samples for the analysis of middle and high boiling bases other than nicotine are shown in Figure 6 and the 43 compounds were identified by their gas chromatographic retention times and mass spectrometric data (Table 2). Figure 6 shows that compared with mainstream smoke, sidestream smoke contains relatively large quantities of low boiling compounds eluting in the first half of the chromatogram.

Gas chromatograms of the sidestream and mainstream smoke samples for the analysis of nicotine showed only two large peaks, nicotine and quinoline (IS).

\section{Spectrophotometric Determination of Ammonia}

The reaction of ammonia with phenol and hypochlorite to form a blue-colored, indophenol-type compound may be subject to interference by some tobacco smoke components such as nicotine and amide (10). The effects of nicotine and acetamide which is a major amide in tobacco smoke (11) were examined.

The extent of interference caused by nicotine in this system was investigated by analyzing aqueous solutions
Figure 5.

Gas chromatograms of low boilling bases in sidestream and malnstream smoke (Bright).
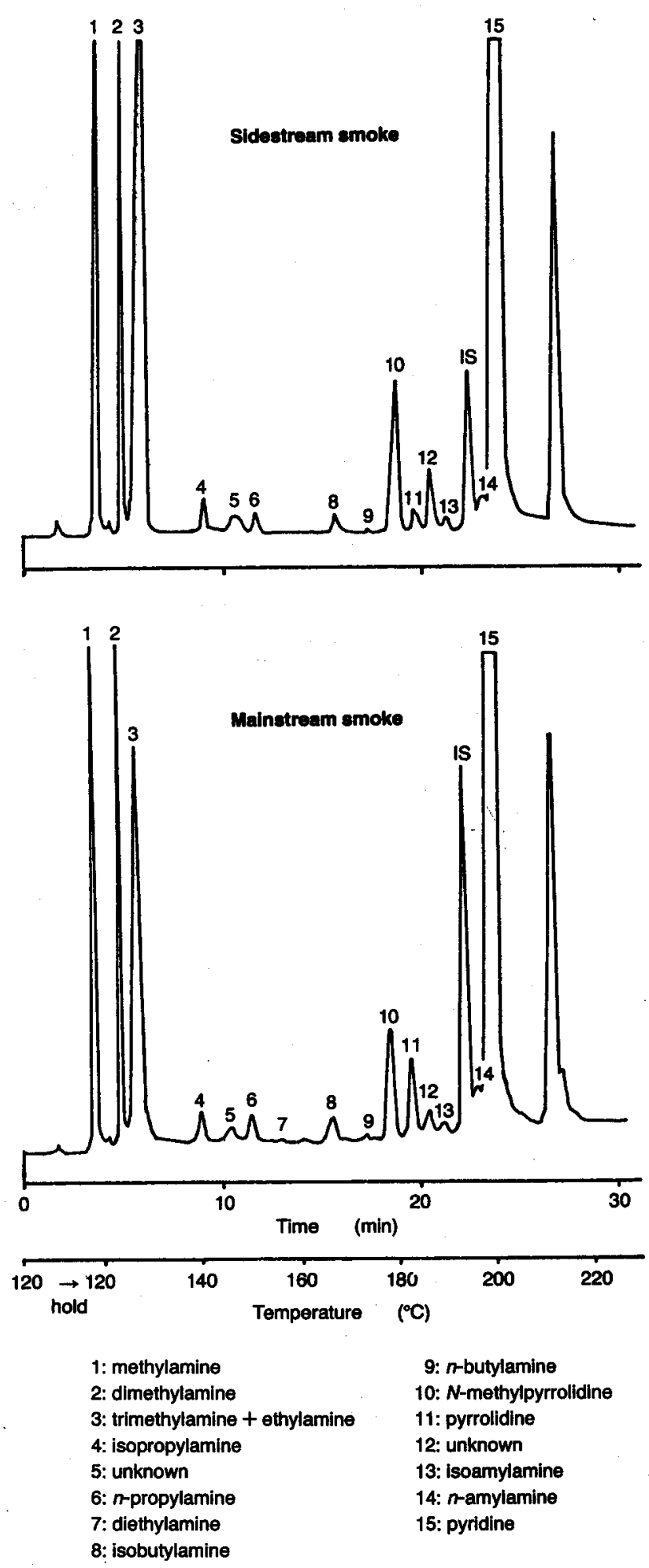

containing various concentrations of ammonia and nicotine, and the results obtained are shown in Table 3. As the concentration of nicotine in the sample solutions of 
Figure 6.

Gas chromatograms of middle and high bolling bases In sidestream and mainstream smoke (Burley) (see Table 2 for identification of peaks).
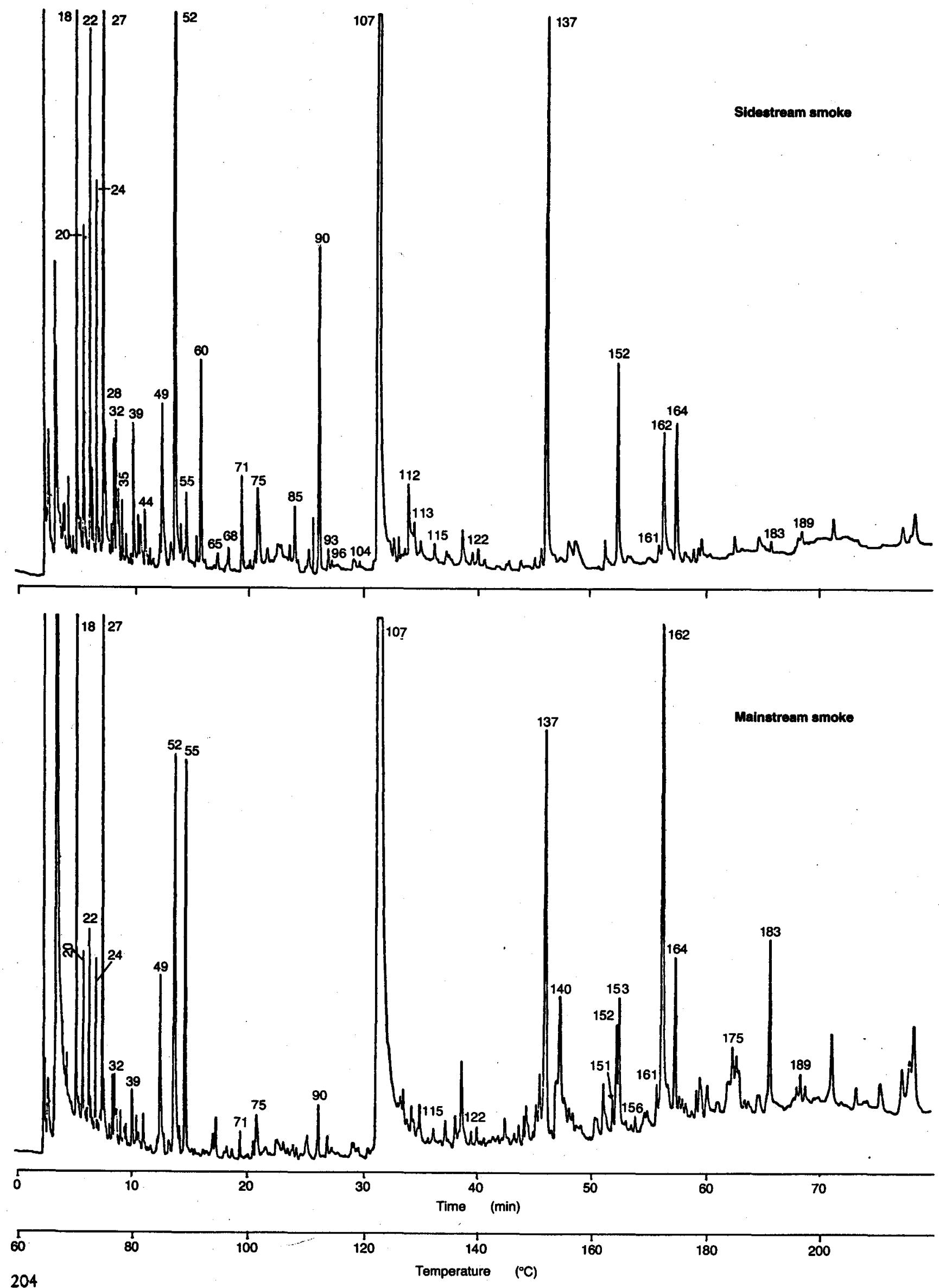
Table 2.

Middle and high bolling bases Identifled In sidestream and mainstream smoke (seo Figure 6).

\begin{tabular}{|c|c|c|c|}
\hline \multirow[b]{2}{*}{$\begin{array}{l}\text { Peak } \\
\text { No. }\end{array}$} & \multirow[b]{2}{*}{ Compound } & \multicolumn{2}{|c|}{ Identification } \\
\hline & & $\begin{array}{c}\mathrm{GC}- \\
\text { retention } \\
\text { time }\end{array}$ & GC-MS \\
\hline 18 & Pyridine & + & + \\
\hline 20 & 2-Picoline & + & + \\
\hline 22 & 2,6-Lutidine & + & + \\
\hline 24 & Methylpyrazine & + & + \\
\hline 27 & 3-Picoline & + & + \\
\hline 28 & 4-Picoline & + & + \\
\hline 31 & Dimethylpyrazine & & + \\
\hline 32 & $\begin{array}{l}\text { 2,5-Lutidine } \\
\text { 2,5-Dimethylpyrazine }\end{array}$ & $\begin{array}{l}+ \\
+\end{array}$ & + \\
\hline 33 & 2,4-Lutidine & + & + \\
\hline 35 & 2,3-Lutidine & + & + \\
\hline 37 & 2,4,6-Collidine & & + \\
\hline 39 & 3-Ethylpyridine & + & + \\
\hline 41 & Methylethylpyrazine & & + \\
\hline 48 & Collidine & & + \\
\hline 49 & 3,5-Lutidine & + & + \\
\hline 52 & 3-Vinylpyridine & & + \\
\hline 55 & 4-tert-Butylpyridine (IS) & & \\
\hline 60 & Pyrrole & + & + \\
\hline 61 & Methylvinylpyridine & & + \\
\hline 68 & Parvoline & & + \\
\hline 71 & 2-Acetylpyridine & + & + \\
\hline 75 & Methylvinylpyridine & & + \\
\hline 90 & 3-Cyanopyridine & + & + \\
\hline 96 & Aniline & + & + \\
\hline 104 & 3-Acetylpyridine & + & + \\
\hline 107 & Nicotine & + & + \\
\hline 113 & Quinoline & + & + \\
\hline 115 & Isoquinoline & & + \\
\hline 119 & $N$-Methylanabasine & & + \\
\hline 122 & 2-Pyrrolidone & + & + \\
\hline 137 & Myosmine & + & + \\
\hline 138 & $\begin{array}{l}\text { 5,6-Dihydro- } \\
2(1 H) \text {-pyridone }\end{array}$ & & + \\
\hline 139 & 2- or 4-Methylimidazole & & + \\
\hline 143 & $\begin{array}{l}\text { 3-Phenylpyridine } \\
\text { Benzimidazole }\end{array}$ & & + \\
\hline
\end{tabular}

Table 2 (cont'd)

\begin{tabular}{l|l|c|c}
\hline \multirow{2}{*}{$\begin{array}{l}\text { Peak } \\
\text { No. }\end{array}$} & Compound & \multicolumn{2}{|c}{ Identification } \\
\cline { 3 - 4 } & & $\begin{array}{c}\text { GC - } \\
\text { retention } \\
\text { time }\end{array}$ & GC-MS \\
\hline 152 & Nicotyrine & + & + \\
153 & Anatabine & + & + \\
156 & 1-Methylbenzimidazole & + & + \\
162 & 3-Hydroxypyridine & + & + \\
164 & 2,3'-Bipyridyl & + & + \\
167 & Bipyridyl & & + \\
175 & 5 -Methyl-2,3'-bipyridyl & & + \\
189 & Cotinine & & + \\
\hline
\end{tabular}

sidestream or mainstream smoke for AutoAnalyzer analysis was $30-700 \mathrm{mg} / \mathrm{l}$, the nicotine found in the sidestream or mainstream smoke may cause the results to be lowered by up to $5 \%$ at maximum.

It is well known that there is a big difference in the amount of ammonia found in sidestream and mainstream smoke. So, the sample solutions which trapped ammonia from sidestream or mainstream smoke were diluted and the ammonia concentrations in the solutions were adjusted to be in the range of $2.5-100 \mathrm{ppm}$; in this range a linear calibration curve for ammonia was obtained.

In order to free the ammonia by mixing the sample sol-

Table 3.

Interference of nicotine in the analytical procedure of ammonla.

\begin{tabular}{c|c|c|c}
\hline \multirow{2}{*}{$\begin{array}{c}\text { Nicotine } \\
(\mathrm{mg} / \mathrm{l})\end{array}$} & $\begin{array}{c}|c| \\
\text { added }(\mathrm{A}) \\
(\mathrm{mg} / \mathrm{l})\end{array}$ & $\begin{array}{c}\text { found }(\mathrm{B}) \\
(\mathrm{mg} / \mathrm{l})\end{array}$ & $\begin{array}{c}\text { Relative } \\
\text { difference* }\end{array}$ \\
\cline { 2 - 3 } 100 & 40 & 39.2 & -2 \\
\hline 500 & 120 & 119.0 & -1 \\
& 20 & 19.0 & -5 \\
& 40 & 38.8 & -3 \\
& 60 & 57.0 & -5 \\
1000 & 20 & 19.2 & -4 \\
& 40 & 38.0 & -5 \\
& 60 & 56.9 & -5 \\
\hline
\end{tabular}




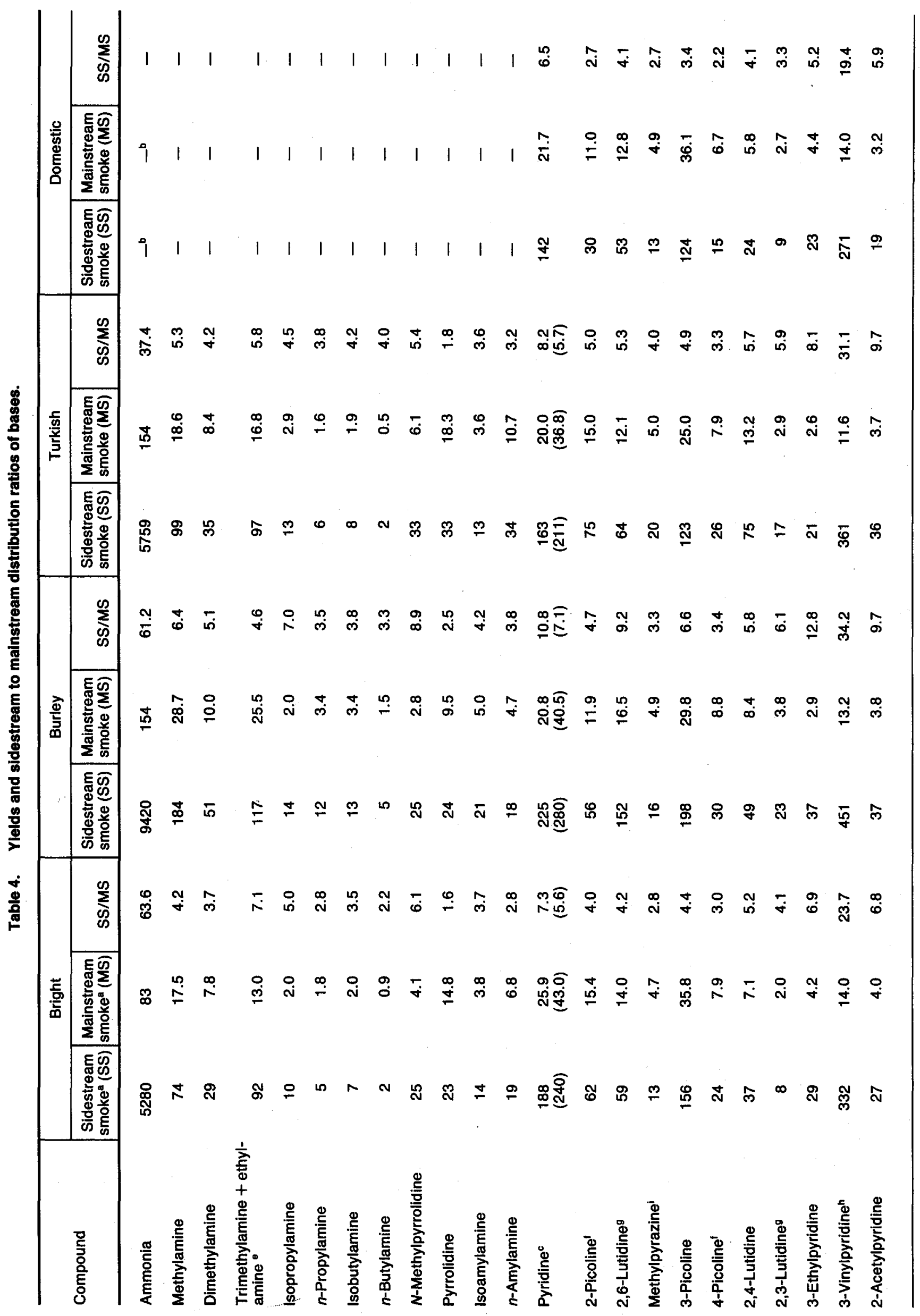




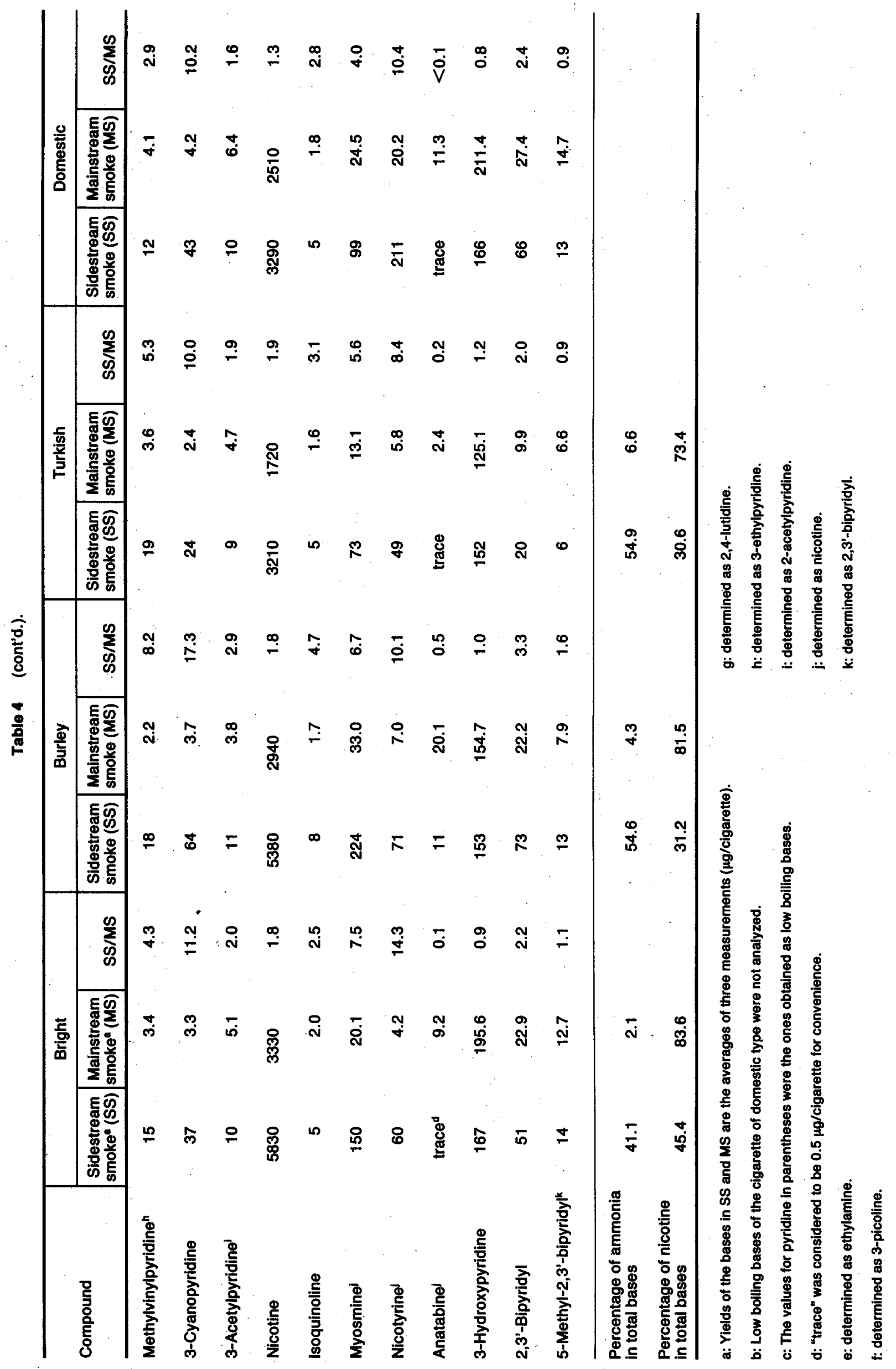


ution $(1.2 \mathrm{ml} / \mathrm{min})$ with a half volume of boric acid

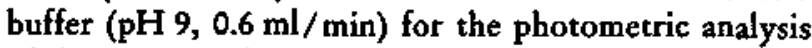
of the ammonia by the AutoAnalyzer, the $\mathrm{pH}$ of all the sample solutions for the AutoAnalyzer was adjusted to 5 with aqueous sodium hydroxide solution in advance.

The possible interference of acetamide was studied by determining if acetamide would decompose to form ammonia during distillation. An analysis of an aqueous solution containing $1000 \mathrm{mg} / 1$ of acetamide $(288 \mathrm{mg} / 1$ as ammonia) gave a value of $0.4 \mathrm{mg} / \mathrm{l}$ of ammonia, which means that, if the ammonia detected originated from hydrolysis of the amide group, $0.1 \%$ of acetamide in the sample solution was hydrolyzed. It thus appears that acetamide does not interfere significantly in this procedure.

\section{Distribution of Bases between \\ Sidestream Smoke and Mainstream Smoke}

Yields from sidestream smoke and mainstream smoke and the sidestream smoke to mainstream smoke distribution ratios of low boiling bases of three varieties of cigarette and middle and high boiling bases of four varieties of cigarette are given in Table 4.

Domestic tobacco is excluded from the following discussion because of the lack of data on low boiling bases. The chief components in all sidestream smoke samples were ammonia and nicotine and the sum of their yields accounted for $86-87 \%$ of the total bases determined. 3-Vinylpyridine was the third most abundant base, followed by pyridine, 3-hydroxypyridine and 3-picoline. In the mainstream smoke samples, the level of ammonia was not as abundant as in the sidestream smoke sample. Nicotine was the most abundant and accounted for 73-84 \% of the total bases determined, followed by 3-hydroxypyridine, ammonia, 3-picoline and pyridine. Burley tobacco smoke contained the greatest amount of bases, followed by Bright and Turkish in that order.

As shown in Table 4, the yields of most bases in sidestream smoke samples were larger than those in mainstream smoke samples and thus the distribution ratios of bases between sidestream smoke and mainstream smoke were generally larger than 1.0 . For all three varieties of tobacco, ammonia showed the largest SS/MS distribution ratios, 37-64, which agree fairly well with those reported by Brunnemann et al. (6) but are smaller than those of Johnson et al. (4).

The far greater prevalence of ammonia in sidestream smoke than in mainstream smoke seems to be attributable to the following (12): 1 . the reducing atmosphere under comparatively low temperature at the time of the formation of sidestream smoke is advantageous for the formation of ammonia, and 2. some ammonia formed in mainstream smoke may be absorbed by the tobacco through which the mainstream smoke passes.

Of the bases, other than ammonia, which may mainly be formed by the pyrolysis of nicotine, 3-vinylpyridine, 3-cyanopyridine, nicotyrine, and pyridine had relatively large SS/MS values.

From the study of the distribution of radioactivity in smoke condensate from cigarettes containing randomly labeled $\left[{ }^{14} \mathrm{C}\right]$ nicotine, Schmeltz et al. (13) concluded that 3-vinylpyridine, 3- and 4-picoline* and myosmine contained sufficient label to postulate their formation from nicotine during smoking. But as their activity was markedly lower than that observed for nicotine, it was apparent that their formation from nicotine during smoking constituted a minor process. The ratios of the radioactivity of the bases analyzed by Schmeltz et al. (13) including the four bases described above to the radioactivity of nicotine are generally the same as, or larger than the ratios of the amounts of the corresponding bases to the amount of nicotine obtained by the authors. This fact may indicate that the majority of pyridine bases including those analyzed by Schmeltz et al. (13) are formed by the pyrolysis of nicotine in tobacco leaf. An exception is pyridine, whose ratio calculated from Table 4 is larger than that obtained by Scbmeltz et al. (13).

Of the sidestream smoke/mainstream smoke ratios in Table 4, those of low boiling bases such as methylamines and chain derivatives of pyridine were generally large. The sidestream smoke/mainstream smoke ratios of chain derivatives of pyridine in Table 4 agree fairly well with those of volatile pyridines reported by Brunnemann et al. (7).

In Table 4 some compounds can be seen which show relatively small sidestream smoke/mainstream smoke ratios, for example anatabine (about 0.1-0.5), 3-hydroxypyridine $(0.9-1.2)$ and 5 -methyl-2,3'-bipyridyl (0.9-1.6).

All these compounds showing small sidestream smoke/ mainstream smoke ratios are relatively high boiling with the exception of pyrrolidine (1.6-2.5).

Since the sidestream smoke/mainstream smoke ratios of bases are generally larger than 1.0 and since most of the bases including ammonia, methylamines and pyridines have sharp irritating odors, these bases might be one of the major causes for the difference in aroma and irritation between sidestream smoke and mainstream smoke.

\section{REFERENCES}

1. Sakuma, H., M. Kusama, S. Munakata, T. Ohsumi and S. Sugawara: The distribution of cigarette smoke components between mainstream and sidestream smoke, I. Acidic components; Beitr. Tabakforsch. Int. 12 (1983) 63-71.

2. Kaburaki, Y., Y. Mikami, Y. Saida and M. Nakamura: Lower bases of tobacco smoke; Nippon Nogeikagaku Kaishi 47 (1973) 799-806.

\footnotetext{
* 3- and 4-picoline elute together.
} 
3. Neurath, G., H. Ehmke: Apparatur zur Untersuchung des Nebenstromrauches; Beitr. Tabakforsch. 2 (1964) 117-121.

4. Johnson, W. R., R. W. Hale, J. W. Nedlock, H. J. Grubbs and D. H. Powell: The distribution of products between mainstream and sidestream smoke; Tob. Sci. 17 (1973) $141-144$.

5. Yoshida, D.: Determination of nicotine in the sidestream of cigarette smoke; Jpn. Monop. Corp. Cent. Res. Inst. Sci. Pap. 118 (1976) 203-206.

6. Brunnemann, K. D., D. Hoffmann: Chemical studies on tobacco smoke, XXXIV. Gas chromatographic determination of ammonia in cigarette and cigar smoke; J. Chromatog. Sci. 13 (1975) 159-163.

7. Brunnemann, K. D., G. Stahnke and D. Hoffmann: Chemical studies on tobacco smoke, LXI. Volatile pyridines, Quantitative analysis in mainstream and sidestream smoke of cigarettes and cigars; Analyt. Letters 11 (1978) 545-560.

8. Glock, G., M. P. Wright: The relation of nornicotine in tobacco to cigarette smoke aroma and composition; 16th 'Tobacco Chemists' Research Conference, Richmond, Virginia, 1962.

9. Klus, H., H. Kuhn: Verteilung verschiedener Tabakrauchbestandteile auf Haupt- und Nebenstrom- rauch (Eine Übersicht); Beitr. Tabakforsch. Int. 11 (1982) 229-265.

10. Collins, P. F., W. W. Lawrence and J. F. Williams: An automated procedure for the determination of ammonia in tobacco; Beitr. 'Tabakforsch. 6 (1972) $167-172$.

11. Sakuma, H., et al.: 1983 , unpublished data.

12. Wakeham, H.: Recent trends in tobacco and tobacco smoke research; in The chemistry of tobacco and tobacco smoke, ed. by I. Schmeltz, Plenum Press, New York - London, 1972, 1-20.

13. Schmeltz, I., A. Wenger, D. Hoffmann and T. C. T'so: Chemical studies on tobacco smoke, 63. On the fate of nicotine during pyrolysis and in a burning cigarette; J. Agric. Food Chem. 27 (1979) 602608.

Authors'address:

The Japan Tobacco and Salt Public Corporation, Central Research Institute,

6-2 Umegaoka, Midori-ku,

Yokobama, Kanagaqoa, 227, Japan. 